https://doi.org/10.18778/1898-6773.52.1-2.08

\title{
Antropogeneza a teologia
}

\author{
Franciszek M. Rosinski
}

\begin{abstract}
ANTHROPOGENESIS AND THEOLOGY. A significant progress in biblical studies contributed to the decrease or liquidation of the controversy in the interpretation of the origin and evolution of Homo sapiens. Contacts between anthropologists and theologists show a growing tendency, and next to anthropogenesis they refer also to many new problems.
\end{abstract}

Czlowiek już w najdawniejszych czasach interesowal się swoim początkiem, przeznaczeniem, odmiennością od innych istot; dal temu wyraz m.in. w najstarszych wierzeniach religijnych i systemach filozoficznych. W miarę rozwoju badań naukowych, ta pierwotna wizja czlowieka ulegla glębokim zmianom; szczególnie ważny w tym udzial miala antropogeneza. Naukowa rekonstrukcja procesu hominizacji różniła się jednak znacznie od opisu początków ludzkości w Księdze Rodzaju, interpretowanego dotąd raczej w sensie literalnym.

Można by przypuszczać, że szybko upowszechniający się wśród uczonych model ewolucyjnego rozwoju istot żywych, w tym także czlowiekowatych, zachęci teologów do poglębionej analizy wlasnych pozycji, ewentualnie też do pewnych reinterpretacji biblijnego opisu stworzenia, np. w sensie ustalenia jego ponadczasowych

Al. J. Kasprowicza 25, 51-161 Wrocław treści doktrynalnych, ukazania jego specyficznej formy literackiej, uwarunkowanej ówczesnym obrazem świata, wplywami religijno-kulturowymi, sytuacją etniczną i psychiczną adresatów [RAUH 1968, WILDIERS 1985]. Wydawaloby się też, iż ewolucjonizm nie powinien byl wzbudzić istotnych zastrzeżeń teologów, gdyż pewne idee "protoewolucyjne", nawet o abiogennym pochodzeniu niektórych zwierząt lub ich pokrewieństwie filogenetycznym, można spotkać już kilkaset lat przed Lamarckiem i Darwinem we wczesnej literaturze patrystycznej [FOTHERGILL 1966, FRANCOEUR 1969]. Na przyklad św. Bazyli, doktor Kościoła (329-379), w którym wielu autorów widzi jednego $z$ ważniejszych prekursorów Darwina, wypowiada się za samorództwem niektórych owadów, węgorzy i myszy polnych. Dostrzega nawet jakąś więż rodową między ptakami a rybami: "Ich wspólne pochodzenie $z$ wód uczynilo je 
jedną rodziną" (Eis ten heksaemeron, hom. 8). Swięty Grzegorz z Nyssy, doktor Kościola (335-394) byl nawet zdania, iż między decyzją Boga o stworzeniu czlowieka (potencjalnym stworzeniem) a późniejszym faktycznym jego pojawieniem się, czlowiek przeszedl wpierw przez stadium roslinne i zwierzęce: "Sila życiowa zespolila się z naturą fizyczną wedlug pewnego następstwa. Najpierw wlala się $w$ naturę pozbawioną czucia, następnie zrobila krok wyżej wstępując w świat uczucia, a w końcu osiągnęla inteligentne rozumne istoty" (De anima et resurrectione). Dlatego wiele swych przymiotów czlowiek czerpie ze świata zwierzęcego. Swięty Augustyn, doktor Kościola (354-430), w traktacie De Genesi ad litteram, VI wysunąl ideę tzw. rationes seminales. Interpretatorzy widzą $\mathrm{w}$ nich aktywne sily albo zasady, które we wlaściwym czasie i w odpowiednich warunkach sa realizowane w nowych gatunkach, prowadząc ostatecznie do powstania czlowieka. Idea potencjalnego stworzenia, którą w pewnej mierze można określić jako "kreacjonizm ewolucyjny", zostala powszechnie przyjęta i przez caly okres przedscholastyczny cieszyla się dużym uznaniem teologów. Wedlug DoRLODOTA [1921] nie ma w okresie przedscholastycznym żadnego pisarza chrześcijańskiego, który przeciwstawialby się tym ideom, albo który widzialby w tych rationes seminales tylko materialne bierne sily, jak później interpretowali je autorzy (por. FotHERGILL [1966]).

Swięty Tomasz, doktor Kościola (12251274), opierając się na raczej statycznej filozofii arystotelesowskiej wystapil z odmienną interpretacją opisu stworzenia: tylko rośliny i zwierzęta niższe powstaly przy wspóludziale cial ziemskich, natomiast zwierzęta wyższe i czlowieka Bóg stworzyl bezpośrednio. Pogląd ten nie spotkal się jednak z powszechną akceptacją teologów; nie byl też doktryną obowiązującą w calym Kościele. Nadal, choć rzadziej, glosi się stare koncepcje Bazylego, Grzegorza i Augustyna. Wedlug Meaghera, który podsumowal opinie dawniejszych teologów na ten temat, Biblia i literatura patrystyczna ani nie przeciwstawia się ewolucji, ani jej nie popiera: nie bylo bowiem przedtem takiego problemu (wg FOTHERGILL [1966]).

Wprawdzie niektóre teksty biblijne zdają się dopuszczać, czy nawet sugerować interpretację $w$ sensie ewolucyjnym, $n p$. następujące wersety z Księgi Rodzaju: "Niechaj ziemia wyda rosliny zielone ... i stalo się tak" (Rdz. 1, 11); "Niechaj się zaroją wody od roju istot żywych" (Rdz. 1, 20); "Niechaj ziemia wyda istoty żywe różnego rodzaju ... i stalo się tak" (Rdz. 1, 24), jednak egzegeza tzw. wersji kaplańskiej ("źródła P") opisu stworzenia jest bardzo trudna. Na ogól przyjmuje się, iż nie chodzi tu o rozstrzygnięcia zagadnień kosmogonicznych, przyrodniczych, antropogenetycznych. Już Św. Augustyn wskazal, iż Biblia nie jest traktatem naukowym i przestrzegal przed doslowną wykladnią tego tekstu: "Zbyt dziecinnie byłoby myśleć, że Bóg cielesnymi rękoma z mulu utworzyl czlowieka" (De Gen. ad litt. 6, 12). Szkoda, że wielu autorów cytujących biblijny opis stworzenia i jego interpretatorów nie wzięlo słów tych pod uwagę: można bylo uniknąc niejednego konfliktu między teologami a przyrodnikami.

Tak zwany pierwszy opis stworzenia powstal prawdopodobnie w okresie niewoli babilońskiej, a więc w środowisku zdominowanym przez silnie rozbudowany politeizm; w Babilonii "według urzędowego spisu bogów, przeprowadzonego w IX w. p.n.e. panteon liczyl 65000 wyższych istot" [DuRANT 1981: 215]. Miasta, a nawet 
wioski mialy swych lokalnych bogów, rodziny czcily osobne bóstwa ogniska domowego, do których się modliły i którym składaly ofiary; nawet poszczególny czlowiek mógl mieć swego boga-opiekuna. Według DABBROWSKIEGO [1957: 123] "... nie tylko każdy przejaw życia natury stanowil $w$ Babilonii oddzielne bóstwo, ale niejednokrotnie mnożono personifikacje cial niebieskich, zależnie od ich dzialania"; np. bogiem dobroczynnego dzialania słońca byl Szamasz, ale szkodliwego żaru słonecznego - Nergal. Król, według mezopotamskich tradycji, partycypowal funkcjonalnie w godności (anutu) najwyższego bóstwa, często wymienia się go razem $z$ bogami; przed imieniem króla stawiano w pismach hieroglificznych znak symbolizujący boga, a słowo królewskie ma moc podobną jak slowo bogów (zob. FRAINE [1970]). Król Nabukadnezar uważał się za "prawowitego syna Marduka" [THOMPSON 1965: 118]. Najbardziej rozwiniętą antropolatrię spotykamy w Egipcie, gdzie faraona traktowano jako prawdziwe bóstwo, równorzędne $z$ innymi bogami.

W takiej sytuacji konkretno-plastyczny opis biblijny stworzenia świata i czlowieka stanowil wyzwanie tradycyjnemu porządkowi rzeczy i panującym poglądom politeistycznym, a konstrukcyjnie byl niejako antytezą koncepcji teogonicznych i mitów. Kolejno i konsekwentnie autor, prawdopodobnie kaplan, przeprowadza "demontaż" różnych bóstw; np. zbuntowaną boginię chaosu Tiamat, pokonaną przez Marduka, zdegradowano tu do roli stworzenia, zupelnie zależnego od Boga; albo czczone ciala astralne, decydujące o losach ludzkich, sprowadzono do rzędu pospolitych źródel światla. Podobnie wszystkie inne rzeczy, rośliny i zwierzęta, co do pochodzenia swego i funkcji są tylko stworzeniami, poddanymi wladzy czlowieka; a więc w żadnym przypadku nie można uznawać ich wyższości przez oddawanie im kultu. Również sam czlowiek, nawet jeśli jest królem, nieraz otaczanym nimbem boskości, nie ma jednak żadnych prerogatyw bożych; nie jest emanacją bóstwa, ani żadnym pólbogiem czy bogiem, któremu należałoby oddawać cześć boską, gdyż ukazane jest jego pochodzenie $z$ prochu ziemi, z której przez Stwórcę zostal "uczyniony" (Rdz. 1, 26), od którego calkowicie zależy, zaś próba zrównania się z Bogiem nieuchronnie kończy się tragicznie (Rdz. 3, 22). Proces stworzenia nie zostal jednak ukazany za pomocą abstrakcyjnego wywodu, ponieważ ludzie, dla których autor pisal "wskutek swej semickiej mentalności (...) byli calkiem niezdolni do uchwycenia abstrakcyjnego pojęcia stworzenia" [HARRINGTON 1984: 210]. Przedstawienie natomiast kreacji na podobieństwo pracy ręcznej, dobrze im znanej, w której zależność surowca i wytworzonego zeń produktu od wykonawcy jest oczywista, musialo silnie przemówić do ich wyobraźni i pierwotnej logiki.

Biblijny opis stworzenia jest kosmologią kreacyjną o wyraźnym profilu monoteistycznym. Tekst charakteryzuje relacje między transcendentnym Bogiem a zależnym od niego swiatem, zdecydowanie przeciwstawia się poglądom politeistycznym i obiegowym mitom o powstaniu świata, np. wskutek walki bogów. Wszystko jest dzielem jednego stwórcy, nie ma sil wspóldzialających lub sprzeciwiających się, nie ma prapierwiastka zła, od którego pochodzilyby złe byty, jak w religii Iranu [KAPELRUD 1979, HARRINGTON 1984]. Dzięki decyzji Bożej zostaje zainicjowany proces powstania roślin i zwierząt; a więc nie ma tu miejsca dla "bóstw wegetacji znanych z pogańskiego otoczenia Izraela, których śmierć i zmartwychwstanie 
czczono w pelnych wyrazu - a niekiedy nawet w orgiastycznych kultach", bezsensowna staje się zoolatria, zwlaszcza potworów morskich [TRILLING 1980: 36].

Choć autor "demitologizuje" ówczesne teogonie, relacjonujące nieraz szczególowo i barwnie, niekiedy nawet drastycznie rodowody bogów i niższych istot [ELIADE 1978], to jednak sam korzysta częściowo z formy literackiej mitu, transponując niektóre fakty, akcje i ich uzasadnienie aż na początek czasu, stosując tzw. etiologiczne opowiadanie ("etiologię biblijną"), przy czym "sposób przedstawiania jest taki jak w micie. Podstawy ludzkiego życia zostają zakotwiczone w zdarzeniach, odgrywających się w praczasach" (PANNENBERG [1983: 483]; por. MANNING [1973]).

Opis stworzenia stanowi cykl czasowo zamknięty o wzrastającej doniosłości wydarzeń. Taką formę przedstawienia zdarzeń, ujmowanych w symboliczny schemat 7-dniowy, przy czym kulminacja akcji następuje w ostatnim dniu, spotykamy już w starożytnej literaturze Wschodu. Jest to jednak umowna stylizacja, której nie trzeba traktować doslownie. Nadto w opisie kreacji można zauważyć tzw. styl katalogowy wskutek uszeregowania poszczególnych decyzji $i$ ich wykonanie $w$ pewien "katalog dzialań". Formę katalogową znano i stosowano już w najstarszym piśmiennictwie wschodnim [TRILLING 1980]. $\mathrm{Z}$ literackiego punktu widzenia powstała jednak przez to "jawnie sztuczna kompozycja" (HARRINGTON [1984: 210]; por. HAAG, HAAS, HÛ́RZELER [1962]). Zwięzla uwaga końcowa, iż "Bóg widzial, że wszystko, co uczynil, było bardzo dobre" (Rdz. 1, 31), stanowi wyraźne przeciwstawienie się koncepcjom 0 istnieniu rzeczy immanentnie zlych lub wierzeniom dotyczącym mocy kreacyjnej bogów zlych czy też demonów.
Z powyższego zdaje się wynikać, iż w tekście biblijnym nie chodzi zasadniczo o ustalenie, czy kreacja miala przebieg długo- lub krótkotrwaly, czy stanowila continuum cudownych ingerencji albo czy po zadecydowaniu danej akcji dalszy jej przebieg odbywał się już samorzutnie dzięki tkwiącym w przyrodzie silom i jej prawom rozwoju. Nasuwa się więc pytanie, dlaczego ewolucjonizm, zwlaszcza zastosowany do czlowieka, wywolal wśród teologów, szczególnie w początkowej fazie, tyle niepokoju, a w wielu przypadkach negatywne reakcje.

Trudno przypuszczać, iż ewolucjonizm, zwlaszcza stopniową biologiczną hominizację, odrzucano dlatego, ponieważ teoria ta stala się przyczyną "kopernikańskiego przewrotu" w biologii. Niewątpliwie destabilizowala scholastyczne poglądy na świat i czlowieka. Wydawalo się, iż ustalony hierarchiczno-teleologiczny porządek kosmiczny zostal naruszony i zastapiony przez dynamiczny, ale bezkierunkowy proces ciąglych przemian, spowodowanych przez ślepo dzialające sily przyrody. Wydaje się jednak, iż najbardziej przyczynil się do zaostrzenia konfliktu między teologami a zwolennikami ewolucji czlowieka sens antykreacjonistyczny, antyteologiczny, antybiblijny, jaki tej teorii, początkowo dość slabo uzasadnionej, wielu autorów nadawalo. Wywolalo to zrozumiale reakcje obronne i polemiki, nie zawsze wlaściwie ukierunkowane i rzeczowe. Jak wskazuje WILDIERS [1985: 166], "nauka, filozofia i teologia atakowaly siebie nawzajem w bardzo nieodpowiedzialny sposób, przy czym zarówno uczeni, jak i teologowie, często przekraczali swoje kompetencje (...). Jeśli chodzi o teologów, to często widzieli oni w ewolucjonizmie naukę, którą wymyślono wyłącznie po to, aby pogrzebać religię $\mathrm{i}$ chrześcijaństwo (...) Ernest Haeckel 
(1834-1919) stwierdzil wprost, że teoria ewolucji oznacza ostateczny cios dla chrześcijaństwa. Teoria ewolucji, zamiast sklonić teologię do ponownego przemyślenia nauk wiary, przyczyniala się raczej do usztywnienia starych stanowisk".

Negatywne ustosunkowanie się do ewolucji człowieka nie bylo jednak wśród teologów katolickich zjawiskiem powszechnym, nie zostalo też nakazane przez Urząd Nauczycielski Kościola; przez długi czas nie bylo również żadnej urzędowej wypowiedzi na ten temat. Już w drugiej polowie XIX w. i w pierwszej polowie XX w. można wymienić szereg wybitnych i wplywowych autorów, którzy wykazywali, że ewolucjonizm, również zastosowany do czlowieka, nie zagraża podstawom wiary. Zwolennikiem Darwina byl m.in. sławny kardynal Newman, który nie widzial powodów, aby uznać darwinizm za sprzeczny z wiarą; jego zdaniem "byloby czymś równie dziwnym, gdyby malpy mialy być tak podobne do czlowieka bez jakiegokolwiek historycznego związku między nimi, jak to, gdyby obecność skamienialych kości $w$ skalach nie byla poprzedzona jakimś procesem, który do tego doprowadzil" (Sundries 83, cytow. wg WILDIERS [1985: 165]. Za ewolucją ciala ludzkiego wypowiadali się np. także Bonomelli, Dorlodot, d'Estienne, Leroy, Mivart, Zahn.

Pierwsza, bardziej autorytatywna wypowiedź lokalnej wladzy kościelnej na temat antropogenezy biologicznej pochodzi z 1860 r. Podczas synodu prowincjalnego w Kolonii biskupi niemieccy uznali pochodzenie ciala ludzkiego $\mathrm{z}$ istot podludzkich za pogląd calkowicie sprzeczny $z$ Pismem sw. i wiarą, i wyraźnie opowiedzieli się za ścislym monogenizmem w sensie pochodzenia calej ludzkości z pierwszego czlowieka Adama zaś odmienne zdanie również uznali za sprzeczne z Biblią (Collectio
Lacensis V, 292; zob. ALSZEGHY [1969], WILDIERS [1985]). Juź 10 lat później zagadnieniem biologicznej ewolucji czlowieka zajęto się w czasie obrad Soboru Watykańskiego I (1870), podczas których wysunięto nawet propozycję, aby oglosić pochodzenie calej ludzkości od pierwszej pary za dogmat wiary. Przerwanie obrad nie pozwoliło na gruntowniejsze zajęcie się tą problematyką. Ograniczono się do ogólnikowego stwierdzenia, iż między nauką a wiarą nie może być sprzeczności. Wielu jednak ówczesnych znanych teologów, jak np. Baisi, Boyer, Daffara, Huster, Jungmann, Katschaler, Mazella, Perrone, Rabeneck, Ruffini, Sagües, Scheeben, odrzucalo ewolucyjne pochodzenie człowieka i koncepcję tę uważalo za niezgodną $\mathrm{z}$ wiarą.

Do 1909 r. nie ma żadnej jednak wypowiedzi ogólnokościelnej na temat antropogenezy, co thumaczono brakiem dostatecznego uzasadnienia ewolucjonizmu przez nauki przyrodnicze [ALSZEGHY 1969]. Z tego roku pochodzi dokument Papieskiej Komisji Biblijnej, w którym wymienia się m.in. specjalne stworzenie czlowieka, monogeniczne pochodzenie rodzaju ludzkiego i jego jednośc. Jest rzeczą interesującą, iż formula peculiaris creatio hominis nie zostala jednak bliżej sprecyzowana; nieraz interpretowano ją $\mathrm{w}$ ten sposób, że bezpośredni akt stwórczy dotyczyl nie tylko duszy, ale i ciala czlowieka. Wedlug sekretarza tejże Komisji, Janssena (Summa Theol. 7, 675) nie miala ona jednak na celu wykluczyć powstanie ciala w drodze ewolucji, ani też, jak później wyjaśniono (1948) powstrzymać uczonych od dalszych badań w tej dziedzinie [SŁOMKOWSKI 1957, ALSZEGHY 1969].

Należy tu nadmienić, że dokumenty Papieskiej Komisji Biblijnej, choć cieszą się wielkim autorytetem, nie są mimo to 
wypowiedziami doktrynalnymi o charakterze nieomylnym; określają niekiedy, czy jakaś nauka może być podtrzymywana w danym kontekście kulturowym bez spowodowania zagrożenia dla wiary. Mają więc w dużej mierze znaczenie praktyczne i stanowią $w$ tych zagadnieniach pewną linię wytyczną dla wiernych, jak dlugo dana sytuacja kulturowa nie ulega zmianie i póki pogląd przeciwny nie zostanie poparty mocniejszymi argumentami [ALSZEGHY 1969].

To stosunkowo ostrożne stanowisko zajęte przez Komisję Biblijną, nie zadowalalo jednak wielu teologów. W 1925 r. przywódca integrystów msgr Benigni chcial doprowadzić do urzędowego potępienia ewolucjonizmu; dzięki interwencji kardynalów Bournea, Erlego, Maffi'ego i Merciera do tego nie doszlo [BEGOUIN 1945].

Dopiero 30 XI 1941 r. papież Pius XII ustosunkowal się, w przemówieniu do czlonków Papieskiej Akademii Nauk, do zagadnienia hominizacji. Wyrazil pogląd, iż pochodzenie ciala ludzkiego drogą ewolucji $z$ istot niższych nie zostalo jeszcze udowodnione i dopiero dalsze badania mogą rzucić pewniejsze światlo na to zagadnienie. Wypowiedzial się jednak za tym, że czlowiek może się rodzić tylko $z$ czlowieka i że czlowiek dzięki swej duszy duchowej wykazuje wyraźną wyższość nad zwierzętami (Acta Apost. Sed. 1941, 33).

W encyklice Divino afflante Spiritu z $1943 \mathrm{r}$. w sprawie interpretacji pierwszych rozdzialów Księgi Rodzaju jest napisane, iż "możliwą jest rzeczą, że niektóre pytania w ogóle nie otrzymają zadowalającej odpowiedzi. Chodzi bowiem niekiedy o rzeczy tak dalekie od teraźniejszości i tak obce życiu teraźniejszemu, że dla egzegetów pozostaną one tajemnicą, bo każda wiedza posiada takowe i żadnym wysilkiem nie dają się one rozwiązać" (cyt. wg SkomKOWSKIEGO [1957]).

Szczególowiej ustosunkowal się Pius XII do tej problematyki $w$ encyklice Humani generis z 1950 r., w której można zauważyć próbę zbliżenia stanowiska Kościola do teorii ewolucyjnych. Odrzuca jednak skrajny pogląd ewolucyjny o zabarwieniu monistycznym, panteistycznym i antyreligijnym; zezwala na dyskusję nad ewolucją ciala ludzkiego z żyjącej materii; nie można natomiast tlumaczyć powstania duszy ludzkiej na drodze ewolucji; przy tym wszystkim zaleca ostrożność, ponieważ uważa problem ewolucji czlowieka nadal za nie rozwiązany. Wypowiada się przeciw poligenizmowi, choć nie w sposób kategoryczny i ostateczny, lecz dlatego ponieważ nie wiadomo, jak można pogodzić poligenizm $z$ wiarą o grzechu pierworodnym.

Jest rzeczą charakterystyczną, iż papież Pawel VI w alokucji do grupy teologów w 1966 r. nie określa już ewolucjonizmu jako hipotezę, lecz jako teorię. "Stosując ją do czlowieka należy pamiętać, iż dusza ludzka zostaje stworzona indywidualnie i bezpośrednio przez Boga. Nie można przyjąć poligenizmu, który nie zostal dotąd naukowo udowodniony, jeśli wiąże się z tym zaprzeczenie grzechu pierworodnego" (L'Osservat. Rom. 16.7.1966).

Nasuwa się pytanie, czy można spodziewać się w przyszlości doktrynalnej wypowiedzi Urzędu Kościola przeciw ewolucji czlowieka. Zdaniem ALSZEGHY'EGO [1969] jest to nieprawdopodobne, skoro dotychczasowe argumenty wysuwane przeciw ewolucjonizmowi, zwłaszcza przeciw hominizacji, nie zdolaly sklonić władz Kościola do wypowiedzenia się przeciw niej, trudno zaś spodziewać się jakichś nowych, bardziej przekonujących argumentów teologicznych przeciw antropogenezie. Obecnie, wedlug SŁomKowsKIEGo 
[1957: 175] "... większość wspólczesnych teologów jest zdania, iż ani na podstawie Pisma Swiętego, ani wskutek racji filozoficznych czy teologicznych nie można odrzucić teorii ewolucji zastosowanej do ciala ludzkiego, a wielu z nich, zwlaszcza spośród biologów i antropologów, wypowiada się pozytywnie za teorią ewolucji".

Na tę pozytywną zmianę zlożyło się wiele czynników. Coraz powszechniej widzi się w ewolucjonizmie poważną, dobrze udokumentowaną teorię przyrodniczą; na ogól nie traktuje się jej też już jako broń ideologiczną, antyreligijną. Zrozumiano, iż antropologia również nie może dyktować jakiegoś integralnego światopoglądu, gdyż tylko konkretne dane naukowe mają moc zobowiązującą [SALLER 1958, HENRY 1966]. Zrezygnowano też $z$ wielu filogenetycznych spekulacji i ryzykownych ekstrapolacji. Zarówno antropologowie jak i teologowie uświadomili sobie granice wlasnych kompetencji [RAUH 1968]. Można nawet zauważyć wzrastające zainteresowanie teologów wynikami badań antropogenetyków oraz dowartościowanie aspektu humanistycznego hominizacji $u$ antropologów. Według BRŌKERA [1969: 265], obecnie "... katolik nie będąc zobowiązany do jakiegoś szczególowego uzasadnienia może mówić o zgodności nauki o ewolucji z nauką o objawieniu, a ponadto także o pochodzeniu ciala ludzkiego od ciala zwierzęcego". Dzięki zas licznym odkryciom szczątków Hominidae rekonstrukcja poszczególnych faz czlowiekowatych stała się pewniejsza, a przebieg antropogenezy, przynajmniej w ogólnych zarysach, bardziej przejrzysty.

Do zmniejszenia lub zlikwidowania wielu dawniejszych trudności przyczynil się też znaczny postęp badań biblijnych. Pozwolił on zrezygnować z metodologicznie niewłasciwej interpretacji literalno-historycznej pierwszych rozdzialów Księgi Rodzaju. Przeprowadzono poglębioną analizę krytyczną tego tekstu celem ustalenia wlaściwego jego sensu i osiągnięto $w$ tej dziedzinie istotne, a zarazem bardzo interesujące wyniki, choć jeszcze wielu problemów nie udało się zadowalająco rozwiązać [FILIPIAK 1979].

Obecnie raczej nie dochodzi już do ostrych polemik między przedstawicielami teologii i antropologii; coraz częściej dochodzi nawet do wzajemnych kontaktów i rzeczowego dialogu. Na przyklad w dniach od 24-27 V 1982 r. Papieska Akademia Nauk zorganizowala spotkanie najwybitniejszych specjalistów z zakresu antropologii, prymatologii i biochemii celem rozpatrzenia niektórych zagadnień spornych z zakresu antropogenezy, np. kwestii datowania dywergencji czlowiekowatych od innych naczelnych [CHAGAS 1983].

Niektóre zagadnienia interesują zarówno antropologów jak i teologów, choć z różnych punktów widzenia; wielu teologów jest także antropologami, niemaly jest ich udzial np. w badaniach ludów pierwotnych; fascynują poglądy Teilharda de Chardin. Wydaje się, iż kontakty między antropologami a teologami wykazują tendencję wzrostową i prócz antropogenezy dotyczą także wielu nowych zagadnień.

\section{Piśmiennictwo}

ALSZEGHY Z., 1969, Ewolucjonizm a Urzqd Nauczycielski Kosciola. Concilium 1-10, 1966/7, s. 276-280.

BEGOUIN C., 1945, Quelques souvenirs sur le mouvement des idkes transformistes dans les milieux catholiques. Paris.

BROKKER W., 1969, Aspekry ewolucji. Concilium 1966/7, 110, s. $265-275$.

CHAGAS C. (ed.), 1983, Recent advances in the evolution of Primates, May 24-27, 1982. Pontificia Academia 
Scientiarum, Civ. Vaticana.

DĄBROWSKI E., 1957, Religia Babilonii i Asyrii. E. Dąbrowski (red.), Religie Swiata, Warszawa, s. 121 132.

DORLODOT H. de, 1921, Le darvinisme au poins de vue de I'orthodaxie catholique, t. 1, Coll. Lovanium, Bruxelles.

DURANT W., 1981, Kulturgeschiche der Menschheit, t. 1., Ullstein, Frankfurt a.M.

ELIADE M., 1978, Geschichte der religiösen Ideen, t. 1, Herder, Freiburg.

FILIPIAK M., 1979, Biblia o czlowieku, Towarzystwo Nauk. KUL, Lublin.

FOTHERGILL P. G., 1966, Chrzescijanie wobec ewolucji, Warszawa.

FRAINE J. de, 1970, Kb̈nig, H. Haag (Hrsg.), BibelLexikon, St. Benno-Verl., Leipzig, s. 969-972.

FRANCOEUR R.T., 1969, Honzonty ewolucji, Warszawa.

HAAG H., A. HAAS, J. HÜRZELER, 1962, Evolution und Bibel, Herder, Basel.

HARRINGTON W. J., 1984, Klucz do Biblii, Warzzawa.

HENRY C. F. H., 1966, Theology and evolution, R. L. Mixter (ed.), Evolution and christian thought soday, WM. B.
Eerdmans, Publ. Co., Grand Rapids, s. 190-221.

KAPELRUD A. S., 1979, Die Theologie der Schöpfung im Alten Testament, Zeitschrift für die Alttestamentliche Wissenschaft 91/2, s. 159-170.

MANNING F. V., 1973, Biblia-dogmat, mit czy tajemnica? Warszawa.

PANNENBERG W., 1983, Anthropologie in theologischer Perspektive, Vandenhoeck u. Ruprecht, Göttingen.

RAUH F., 1968, Evolutionstheorie und Theologie. Anthropologie und Humangenetik, G. Fischer Verl., Stuttgart, s. 28-35.

SALLER K., 1958, Das Menschenbild der naturwissenschaftlichen Anthropologie, Wissen der Zeit, t. 1, München.

SLOMKOWSKI A., 1957, Problem pochodzenia czlowieka, Pallottinum, Poznan.

THOMPSON J. H., 1965, Biblia i archeologia, Warszawa. TRILLING W., 1980, Srworzenie i upadek, Warszawa.

WILDIERS N. M., 1985, Obraz fwiata a teologia, Warszawa.

Referal wygloszony na Konferencji Antropologicznej w Blażejewku, we wrześniu 1985 r.

\section{Zus a m m e n a s u n g}

Die Evolutionstheorie, die im Prinzip eine dynamische Entwicklung der Lebewesen, selbst des Universums beinhaltet, stellte in Frage das bisherige von Philosophie, Theologie und Wissenschaft geprägte statische Weltbild. Die Auseinandersetzungen zwischen den Vertretern der entgegesetzten Meinungen, besonders im Anfangsstadium, als das Evolutionskonzept eine verhältnismässig schwach fundierte Hypothese war, wurden leider durch weltanschauliche Momente stark beeinflusst, wobei oft die jeweiligen Aussagekompetenzen methodisch und sachlich nicht gebührend gewahrt wurden.

In den oft ausrufernden Polemiken wurden zudem wesentliche Elemente nicht entsprechend berücksichtigt. Schon bei den Kirchenlehrern, z.B. bei Basilius, Gregor v. Nyssa, Augustinus, aber auch bei späteren Theologen, sind verschiedene Ansätze feststellbar, die man als "protoevolutionistisch" bezeichnen könnte, wobei sogar Ansichten über ein abiogenetisches Entstehen höherer Lebewesen, inkl. Wirbeltiere vertreten wurden. Ausserdem kam man schon früh zu der Erkenntnis, dass nicht alle Aussagen des Schöpfungsberichtes verbaliter zu verstehen und interpretieren seien. Die Wortfassung des Textes selbst schließt eine Auslegung im Sinne einer evolvierenden Höherentwicklung des Lebens nicht aus.

Es wurde versucht unter Berücksichtigung des geschichtlichen Rahmens und der vergleichenden Textanalyse des Hexaemeronberichtes seinen ursprünglichen Aussagegehalt und Sinn wie auch die Absicht des Verfassers zu ermitteln. Außerdem wurden die lehramtlichen Entscheidungen in der Frage der Evolution des Menschen und der jetzige Stand der Diskussion erörtert. 